\title{
Denosumab-induced hypocalcemia in a patient with hyperthyroidism: a case report
}

\author{
S.Y. Park ${ }^{1} \cdot$ J. Kim ${ }^{2} \cdot$ H.Y. Chung ${ }^{3}$ (I) \\ Received: 7 May 2021 / Accepted: 29 June 2021 / Published online: 7 July 2021 \\ (C) The Author(s) 2021
}

\begin{abstract}
Denosumab is a humanized monoclonal antibody targeting the receptor activator of nuclear factor kappa-B ligand (RANKL). Denosumab is an effective treatment for osteoporosis but can cause hypocalcemia. We present a case of denosumab-induced hypocalcemia in a patient with hyperthyroidism with a high bone turnover state. A 48-year-old postmenopausal woman was diagnosed with hyperthyroidism and osteoporosis and received antithyroid drugs (propylthiouracil $200 \mathrm{mg} /$ day) and denosumab. After 2 months of taking medication, the patient complained of numbness and tingling in the hands and feet and was diagnosed with hypocalcemia (calcium, $5.8 \mathrm{mg} / \mathrm{dL}$; ionized calcium, $0.83 \mathrm{mmol} / \mathrm{L})$. Alfacalcidol $(0.5 \mu \mathrm{g} / \mathrm{day})$ and calcium carbonate $(3000$ $\mathrm{mg} /$ day) were prescribed. Subsequently, the patient's symptoms improved, and her serum calcium level normalized. The risk of denosumab-induced hypocalcemia may be increased in patients with diseases related to high bone turnover, such as hyperthyroidism; therefore, caution is needed.
\end{abstract}

Keywords Denosumab $\cdot$ Hyperthyroidism $\cdot$ Hypocalcemia $\cdot$ Osteoporosis

\section{Introduction}

Denosumab is a humanized monoclonal antibody targeting the receptor activator of nuclear factor kappa-B ligand (RANKL). It reversibly inhibits osteoclast-mediated bone resorption by preventing the interaction of RANKL with its receptor [1]. The long-term effects of denosumab in preventing fragility fractures and continuously improving bone mineral density have been reported in the FREEDOM study and its extension trial [2, 3]. Denosumab is widely prescribed because it does not require dose adjustment according to renal function and does not cause any flu-like symptoms, unlike bisphosphonates, when administered [4]. Several

\section{H.Y. Chung}

hychung@khnmc.or.kr

1 Department of Endocrinology and Metabolism, Kyung Hee University Hospital, Seoul, Republic of Korea

2 Department of Endocrinology and Metabolism, Chaum, Seoul, Republic of Korea

3 Department of Endocrinology and Metabolism, Kyung Hee University Hospital at Gangdong, Kyung Hee University School of Medicine, 892 Dongnam-ro, Gangdong-gu, Seoul 05278, Republic of Korea randomized controlled trials have reported hypocalcemia as a serious adverse reaction to denosumab [3, 5]. A higher incidence of hypocalcemia has been reported among patients with chronic kidney disease [6], malignancy [7, 8], and vitamin D deficiency [9]. It has also been suggested that high bone turnover is associated with denosumab-induced hypocalcemia $[10,11]$. Here, we report a case of denosumab-induced hypocalcemia in a patient with hyperthyroidism with a high bone turnover state.

\section{Case presentation}

A 48-year-old woman visited the hospital complaining of a weight loss of $10 \mathrm{~kg}$, sweating, and palpitations for 7 months. She had experienced a hand tremor 7 months before and frequently took stool. She had spontaneous menopause at the age of 45 years. Estrogen replacement therapy was started but discontinued because of adverse reactions. She was not on any medications for any diseases, including osteoporosis. Her height and weight were $164 \mathrm{~cm}$ and $55 \mathrm{~kg}$, respectively. Regarding vital signs, her blood pressure was $125 / 75 \mathrm{mmHg}$ and heart rate was 113 beats/min. Initial blood test results were as follows: thyroid-stimulating hormone (TSH), $<0.003$ (reference range [RR], 0.3-4.0) $\mathrm{mIU} / \mathrm{L}$; free thyroxine (T4), 2.58 
(RR, 0.89-1.79) ng/dL; triiodothyronine (T3), 4.14 (RR, 0.64-1.52) ng/mL; TSH receptor antibody, 24.24 (RR, $<1.75$ ) IU/L; 25-hydroxyvitamin D, 31 (RR, 30-150) ng/ $\mathrm{mL}$; calcium (Ca), 10.2 (RR, 8.8-10.6) mg/dL; phosphorus (P), 5.1 (RR, 2.5-4.5) mg/dL; albumin, 4.0 (RR, 3.5 5.2) g/ dL; alkaline phosphatase (ALP), 819 (RR, 115-359) U/L; and creatinine, 0.28 (RR, 0.55-1.02) $\mathrm{mg} / \mathrm{dL}$. The T-score of lumbar spine bone mineral density assessed using dual-energy $\mathrm{X}$ ray absorptiometry was -3.8 (L1-4). She was diagnosed with hyperthyroidism and osteoporosis. She received propylthiouracil (200 mg/day), short-acting propranolol (20 $\mathrm{mg}$ /day) for hyperthyroidism, and denosumab $60 \mathrm{mg}$, calcium carbonate (250 mg/day), and cholecalciferol (1000 IU/day) for osteoporosis. Seven weeks after taking the medication, the patient complained of numbness and tingling in the hands and feet. Blood tests revealed $\mathrm{Ca}$ of $6.8 \mathrm{mg} / \mathrm{dL}$ and $\mathrm{P}$ of 3.0 $\mathrm{mg} / \mathrm{dL}$. Even with continuous calcium and vitamin D supplementation, it worsened to $\mathrm{Ca}$ of $5.8 \mathrm{mg} / \mathrm{dL}$ and ionized calcium of 0.83 (RR, 1.13-1.32) $\mathrm{mmol} / \mathrm{L}$. In the acute phase, the patient was supplemented with calcium intravenously and referred to our hospital. At that time, the blood test results were as follows: Ca, $7.8 \mathrm{mg} / \mathrm{dL}$; P, $3.0 \mathrm{mg} / \mathrm{dL}$; albumin, $4.3 \mathrm{~g} / \mathrm{dL}$; ALP, $495 \mathrm{U} / \mathrm{L}$; magnesium, 2.5 (RR, 1.9-2.5) mg/dL; intact parathyroid hormone (iPTH), 312 (RR, 15-65) pg/mL; T3, $4.14 \mathrm{ng} / \mathrm{mL}$; free T4, $1.57 \mathrm{ng} / \mathrm{dL}$; TSH, <0.01 $\mathrm{mIU} / \mathrm{L}$; osteocalcin, 93.5 (RR, 15-46) ng/mL; C-telopeptide, 0.206 (RR, 0.104-1.008) ng/mL; and 25-hydroxyvitamin D, 21 $\mathrm{ng} / \mathrm{ml}$. Active vitamin D was prescribed, and the calcium dose was increased (alfacalcidol $0.5 \mu \mathrm{g} /$ day and calcium carbonate $3,000 \mathrm{mg} /$ day). After 1 month, medications were switched to calcium carbonate $(2500 \mathrm{mg} /$ day $)$ and cholecalciferol (2000 IU/day). The patient's symptoms improved, and her serum calcium level normalized to $9.5 \mathrm{mg} / \mathrm{dL}$. Her iPTH levels and thyroid function test results were also improving (iPTH, 70.3 $\mathrm{pg} / \mathrm{mL}$; T3, $1.56 \mathrm{ng} / \mathrm{mL}$; free T4, $0.88 \mathrm{ng} / \mathrm{dL}$; and TSH, <0.01 $\mathrm{mIU} / \mathrm{L})$ (Fig. 1).

\section{Discussion}

This case report indicates that the risk of denosumab-induced hypocalcemia may be increased in patients with a disease associated with high bone turnover, such as hyperthyroidism. There have been no reports of hypocalcemia with concomitant treatment of hyperthyroidism and osteoporosis with denosumab.

Denosumab inhibits osteoclastic bone resorption and causes an imbalance in osteoclast and osteoblastic activity, leading to hypocalcemia by reducing calcium mobilization from the bone [12]. Some studies have reported that high bone turnover is associated with a higher risk of denosumabinduced hypocalcemia $[10,11,13]$. The underlying mechanism is thought to be that patients dependent on high bone turnover to maintain normocalcemia are more sensitive to bone turnover inhibition by denosumab. It would be helpful to measure baseline bone turnover markers, such as P1NP and C-telopeptide. Both bone resorption markers and bone formation markers decrease when antiresorptive agents are used for osteoporosis, whereas they all increase when anabolic agents are used [14]. Some studies have suggested that there may be a difference in the risk of denosumab-induced hypocalcemia depending on whether antiresorptive agents or anabolic agents are used before denosumab $[9,15]$. Pretreatment with anabolic agents increases the risk of denosumab-induced hypocalcemia compared to the use of antiresorptive agents [9].

Persistent increases in thyroid hormones increase osteoclastic resorption and osteoblastic remineralization, resulting in a high bone turnover state called thyrotoxic osteodystrophy $[16,17]$. Furthermore, increased beta-adrenergic activity in hyperthyroidism is associated with high bone turnover [18]. Rapid loss of T3 and T4 can affect hypocalcemia development [19]. Although data on baseline bone turnover markers were limited, our patient was considered to be in a high bone turnover state because of her elevated ALP levels. In this patient,
Fig. 1 Changes in serum calcium and supplementation of calcium and vitamin $\mathrm{D}$ after administration of denosumab

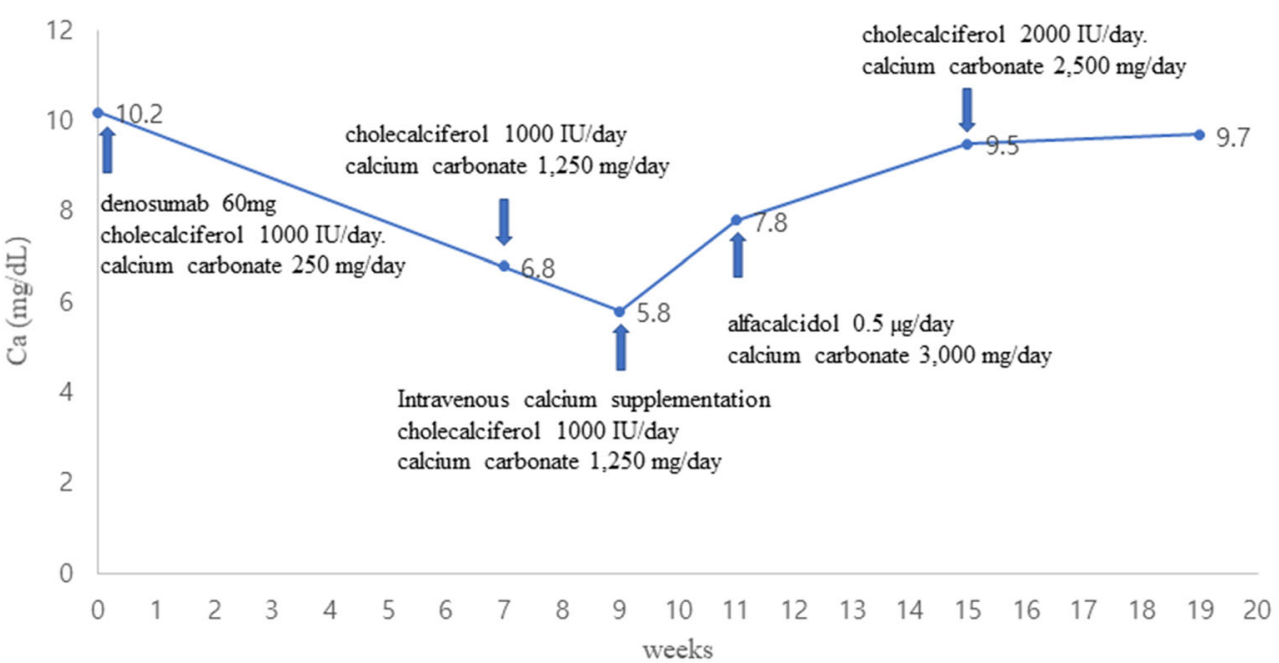


the high bone turnover state was sensitive to the inhibitory effect of denosumab on bone resorption, resulting in hypocalcemia, and rapid loss of T3 and T4 would have exacerbated denosumab-induced hypocalcemia. Hence, before using denosumab, it is necessary to confirm the presence of a disease with a high bone turnover status and to actively supplement calcium and vitamin D. Asymptomatic hypocalcemia should also be detected and treated through short-term follow-up because asymptomatic hypocalcemia can cause cardiac arrest or death [20]. Moreover, if diseases with a high bone turnover state, such as hyperthyroidism, are accompanied, it may be important to first stabilize the diseases themselves before performing osteoporosis treatment with potent antiresorptive agents.

In conclusion, we suggest sufficient calcium and vitamin D supplementation and close monitoring when using denosumab in patients with a disease associated with high bone turnover.

Code availability None.

\section{Declarations}

Ethics approval This study was approved by the Institutional Review Board of Kyung Hee University Hospital at Gangdong.

Consent for publication All authors approved.

\section{Conflicts of interest None.}

Open Access This article is licensed under a Creative Commons Attribution-NonCommercial 4.0 International License, which permits any non-commercial use, sharing, adaptation, distribution and reproduction in any medium or format, as long as you give appropriate credit to the original author(s) and the source, provide a link to the Creative Commons licence, and indicate if changes were made. The images or other third party material in this article are included in the article's Creative Commons licence, unless indicated otherwise in a credit line to the material. If material is not included in the article's Creative Commons licence and your intended use is not permitted by statutory regulation or exceeds the permitted use, you will need to obtain permission directly from the copyright holder. To view a copy of this licence, visit http:// creativecommons.org/licenses/by-nc/4.0/.

\section{References}

1. Delmas PD (2008) Clinical potential of RANKL inhibition for the management of postmenopausal osteoporosis and other metabolic bone diseases. J Clin Densitom 11:325-338

2. Bone HG, Wagman RB, Brandi ML, Brown JP, Chapurlat R, Cummings SR, Czerwiński E, Fahrleitner-Pammer A, Kendler DL, Lippuner K, Reginster JY, Roux C, Malouf J, Bradley MN, Daizadeh NS, Wang A, Dakin P, Pannacciulli N, Dempster DW, Papapoulos S (2017) 10 years of denosumab treatment in postmenopausal women with osteoporosis: results from the phase 3 randomised FREEDOM trial and open-label extension. Lancet Diabetes Endocrinol 5:513-523
3. Cummings SR, San Martin J, McClung MR et al (2009) Denosumab for prevention of fractures in postmenopausal women with osteoporosis. N Engl J Med 361:756-765

4. Jamal SA, Ljunggren O, Stehman-Breen C, Cummings SR, McClung MR, Goemaere S, Ebeling PR, Franek E, Yang YC, Egbuna OI, Boonen S, Miller PD (2011) Effects of denosumab on fracture and bone mineral density by level of kidney function. J Bone Miner Res 26:1829-1835

5. Bridgeman MB, Pathak R (2011) Denosumab for the reduction of bone loss in postmenopausal osteoporosis: a review. Clin Ther 33: $1547-1559$

6. Dave V, Chiang CY, Booth J, Mount PF (2015) Hypocalcemia post denosumab in patients with chronic kidney disease stage 4-5. Am J Nephrol 41:129-137

7. Lechner B, DeAngelis C, Jamal N, Emmenegger U, Pulenzas N, Giotis A, Sheehan P, Tsao M, Bedard G, Chow E (2014) The effects of denosumab on calcium profiles in advanced cancer patients with bone metastases. Support Care Cancer 22:1765-1771

8. Body JJ, Bone HG, de Boer RH, Stopeck A, van Poznak C, Damião R, Fizazi K, Henry DH, Ibrahim T, Lipton A, Saad F, Shore N, Takano T, Shaywitz AJ, Wang H, Bracco OL, Braun A, Kostenuik PJ (2015) Hypocalcaemia in patients with metastatic bone disease treated with denosumab. Eur J Cancer 51:1812-1821

9. Asano T, Shimizu T, Takahashi D, Ota M, Sato D, Hamano H, Hiratsuka S, Takahata M, Iwasaki N (2019) Potential association with early changes in serum calcium level after starting or switching to denosumab combined with eldecalcitol. J Bone Miner Metab 37: 351-357

10. Ishikawa K, Nagai T, Tsuchiya K, Oshita Y, Kuroda T, Ito H, Tani S, Dodo Y, Toyone T, Inagaki K (2018) High bone turnover status as a risk factor in symptomatic hypocalcemia following denosumab treatment in a male patient with osteoporosis. Clin Interv Aging 13: 1929-1934

11. Ishikawa K, Nagai T, Sakamoto K, Ohara K, Eguro T, Ito H, Toyoshima Y, Kokaze A, Toyone T, Inagaki K (2016) High bone turnover elevates the risk of denosumab-induced hypocalcemia in women with postmenopausal osteoporosis. Ther Clin Risk Manag 12:1831-1840

12. Tsvetov G, Amitai O, Shochat T, Shimon I, Akirov A, Diker-Cohen $\mathrm{T}$ (2020) Denosumab-induced hypocalcemia in patients with osteoporosis: can you know who will get low? Osteoporos Int 31:655665

13. Farinola N, Kanjanapan Y (2013) Denosumab-induced hypocalcaemia in high bone turnover states of malignancy and secondary hyperparathyroidism from renal failure. Intern Med J 43:1243-1246

14. Park SY, Ahn SH, Yoo JI, Chung YJ, Jeon YK, Yoon BH, Kim HY, Lee SH, Lee J, Hong S (2019) Position statement on the use of bone turnover markers for osteoporosis treatment. J Bone Metab 26:213-224

15. Okada N, Kawazoe K, Teraoka K, Kujime T, Abe M, Shinohara Y, Minakuchi K (2013) Identification of the risk factors associated with hypocalcemia induced by denosumab. Biol Pharm Bull 36: $1622-1626$

16. Britto JM, Fenton AJ, Holloway WR, Nicholson GC (1994) Osteoblasts mediate thyroid hormone stimulation of osteoclastic bone resorption. Endocrinology 134:169-176

17. Mundy GR, Shapiro JL, Bandelin JG, Canalis EM, Raisz LG (1976) Direct stimulation of bone resorption by thyroid hormones. J Clin Invest 58:529-534

18. Khosla S, Drake MT, Volkman TL, Thicke BS, Achenbach SJ, Atkinson EJ, Joyner MJ, Rosen CJ, Monroe DG, Farr JN (2018) Sympathetic beta1-adrenergic signaling contributes to regulation of human bone metabolism. J Clin Invest 128:4832-4842 
19. Shin T (2015) Guerrero AF (2015) Calcium maelstrom: recalcitrant hypocalcaemia following rapid correction of thyrotoxicosis, exacerbated by pregnancy. BMJ Case Rep 2015:bcr2014206967

20. Huynh AL, Baker ST, Stewardson AJ, Johnson DF (2016) Denosumab-associated hypocalcaemia: incidence, severity and patient characteristics in a tertiary hospital setting. Pharmacoepidemiol Drug Saf 25:1274-1278

Publisher's note Springer Nature remains neutral with regard to jurisdictional claims in published maps and institutional affiliations. 